\title{
Need Analysis on an Availability of Reading Comprehension Module Based on Scientific Approach for Tenth Grade Students: A Study at SMAN 7 Padang
}

\author{
Siti Aminah Nusa ${ }^{1 *}$, Jufrizal $^{2}$, and Zul Amri ${ }^{3}$ \\ 1*English Department, FBS Universitas Negeri Padang, Padang, Sumatra Barat 25131, Indonesia \\ ${ }^{2}$ English Department, FBS Universitas Negeri Padang, Padang, Sumatra Barat 25131, Indonesia \\ ${ }^{3}$ English Department, FBS Universitas Negeri Padang, Padang, Sumatra Barat 25131, Indonesia \\ *Corresponding author. Email: sitiaminahnusa1992@gmail.com
}

\begin{abstract}
Scientific approach is a learning approach suggested by the government in implementing 2013 Curriculum at schools in Indonesia. In supporting learning activities based on scientific approach, learning resources are needed in accordance with the goals of 2013 Curriculum itself. Therefore, the government and education experts have provided learning resources that are considered the most appropriate for achieving learning objectives. Unfortunately, the facts in the field showed that the making of learning resources for students was not made specifically to meet the needs of students. Therefore, research on needs analysis is very important to do. Needs analysis is a very important activity carried out to determine the right teaching material according to the needs of students in the field. In this study, needs analysis was carried out to obtain accurate data regarding students' needs for the procurement of a reading comprehension module that would facilitate them to learn independently with minimal assistance from teachers. The research method used in this study was descriptive research. The subjects of this study were 36 students of class $X$ at SMAN 7, 3 English teachers who taught in class $X$ at SMAN 7 Padang. The results of this study indicated that there were several conditions needed by students in a learning material that would be used by them in the classroom. In general, the results of this study showed that students were more likely to need a learning material, in the form of a reading module, that they could use independently both in class and at home.
\end{abstract}

\section{Keywords: Need Analysis, Reading Comprehension, Scientific Approach}

\section{INTRODUCTION}

Scientific is a learning approach to be used by teachers in teaching students in schools. This approach is a part of 2013 curriculum. As well known, all of schools in Indonesia must use 2013 curriculum in create the teaching learning environment for students. This curriculum requires students to be active and independent learner.

At schools, there are some subjects that have to be mastered by students. Each subject has its own characteristic, difficulty, and simplicity. However, one of the subjects that need special attention is the English subject. In English subject, there are four skills that have to be mastered by students, they are listening, speaking, reading, and writing. All of the skills are interconnected. Among the four skills, reading is a basic skill that should be mastered since all of the skills are taught to the students based on the concept of reading. However, students' skills in reading comprehension will not be owned instantly. Students need a lot of reading practices. They need to be directed on how to accustom themselves to read in detail and systematic.
Unfortunately, the fact found in the field showed something different. The students were not fully directed to active ad independent in learning the reading subject. It caused by the absence of appropriate leaning resource for them. The result of observation and interview with the students and English teacher at SMAN 7 Padang showed that they truly need a learning resource based on their needs in study. Based on the facts in this field, it is indicated that the students at SMAN 7 Padang need a learning resource in the form of module. It is associated to the fact that module is a kind of learning resource which can be used independently by students with a limited help from teachers. Thus, it is important to conduct a need analysis at SMAN 7 in order to find out the students' needs on an availability of reading comprehension module based scientific approach.

The scope of the research is to identify the students' needs on an availability of a reading comprehension module based on scientific approach through need analysis activity.

There are two questions made in this study. First, questions related to student needs. Second, question related to student needs. The research questions in this research are: (1) What are the students' needs on the availability of a 
reading comprehension module based on scientific approach for tenth-grade students of SMAN 7 Padang?, (2) What are the English teachers' needs on the availability of a reading comprehension module based on scientific approach for tenth-grade students of SMAN 7 Padang?

\section{REVIEW OF RELATED THEORY}

A scientific approach means a learning approach that facilitates and directs the students to be the center of learning. In another word, it can be stated that a scientific approach facilitates students to learn actively in order to be independent learners. Moreover, an understanding of the learning stages provided by a scientific approach is important since it distinguishes this approach from others. Especially for this study, the explanation of learning stages based on scientific approach suggested by (Permendikbud (2014), Musfiqon and Nurdyansyah (2015:38-40) are adapted to the appropriate conditions for reading activities at school. As a result, an explanation about activities that can be conducted by students in reading comprehension monologue texts class is stated below.

a. Observing

At this observing stage, students are directed to observe the text to be studied. It aims to help students to have a picture of the text content. This activity will familiarize students to become more focused on understanding the English monologue text that will be studied. Activities that can be conducted by students in the observing stage are: 1) paying attention to the picture/illustration and title of the text; 2) searching for some difficult words on the text and make a list. Then, find the definition, synonym, antonym, or example in English; 3 ) identifying the social function of the text; and 4) asking general questions about the text, such as; what, when, and where.

\section{b. Questioning}

At this stage, students will make questions related to things that are not known about the text being read. This is a continuation of the observing stage. In the questioning stage, the activities that can be conducted by students are: 1) asking $5 \mathrm{~W}+1 \mathrm{H}$ (what, who, when, where, why + how) about text content; 2) asking the main idea provided in the text; and 3) predicting the content/ending of the text content. c. Collecting information

At this collecting information stage, students will gather more in-depth information related to the text that has been read. Activities carried out by students at this stage will be very useful for understanding the whole content of the text. The activities that can be done by students in this stage are: 1) asking about students to read the whole content of the text; 2) asking about the text structure, language features; and 3) answering some questions about text content.

\section{d. Associating}

At this stage, students will process all the information that has been obtained in the previous activity. This activity is very useful to strengthen students' understanding of English monologue texts that have been studied. There are some activities that can be conducted by students: 1) comparing a certain text with another text; 2) differentiating the purpose, structure text, and language feature of some monologue texts; 3) working in pairs (doing some discussion related to the texts); 4) maximizing the use of vocabulary.

\section{e. Communicating}

At Communicating Stage, students will get the opportunity to directly monitor the extent of their knowledge development in understanding the English monologue texts that have been learned. There are many activities that can be done, for example: 1) retelling the text content with own words through written form; 2) arranging the random texts; 3 ) making a conclusion.

In addition, reading is a common activity conducted by people to get certain information through written form. Sheng (in Rozimela, 2014:461) explains reading is a communication process conducted by writer and reader involving the recognition of letters, words, phrases, and clauses. This explanation bears out an understanding that reading is a complex process since there are many things involved during this activity. This statement is supported by Othman et al (2014:102), reading is a complex process because the readers have to involve the quality of thought for the purpose of comprehending the text. Without comprehending the text that has been read, readers will not be considered to have mastered the reading skill. It means that reading is not merely about seeing and spelling the words in certain written form. However, reading is about readers' ability in comprehending each word in order to ensure the information delivered by the writer can be accepted.

The previous explanations have illustrated the definition of reading clearly. Unfortunately, they are not enough to support the purpose of this research. Consequently, a reading definition that describes the reading activity in the context of education is required. Therefore, an explanation delivered by Abidin (2012:148) is taken. He explains that reading is a series of activities conducted by the students to master reading skills under instruction, guidance, and motivation from the teacher. It indicates that reading is not just about the activity to comprehend the message delivered by the writer, but the whole activities which involve all of the students' visual cognition in comprehending and even producing the reading. Besides, the teacher also has an important role to control and motivate students during the reading activity.

However, this study has its own definition of reading. According to this study, reading means an activity conducted by students in order to get the whole information provided in a text. Reading is not only about students' ability to mention or spell the words correctly. Yet, reading is about students' ability to answer all reading questions given to them. Students' ability then can be measured through the number of correct or false answers. If students can gain the minimum score e.g. $80 \%$ for correct answers, it can be stated that students' ability in reading an English text is high. On the other hand, if students can't reach the minimum score, it can be concluded that students' ability in reading an English text is low. 
Furthermore, to get a detailed understanding of reading comprehension, some explanations delivered by some related experts are included. According to McNamara (2007:1), reading comprehension refers to the reader's ability to go beyond the words, to understand ideas and relationships between ideas conveyed in a text. It indicates that the comprehension of reading activity is gained when the reader understands the message delivered by the writer implicitly and explicitly.

In addition, Zaim (2013:49) adds that reading comprehension emphasis on the students' ability to comprehend the content of the text either generally or specifically. It means that reading comprehension is the students' ability in comprehending the text content in detail. Then, Harris and Hodges (in Tennent, 2015:23) highlight that reading comprehension is the construction of meaning from written text through a reciprocal interchange of ideas between the reader and the message in a particular text. It is indicated that reading comprehension will direct the readers to be able to process and conclude the text content they read.

The previous explanations show general definitions of reading comprehension. Those definitions are not really close to the reading comprehension that students do in the classroom. Then, in order to make it more specific, another expert's point of view is needed. Suyoto (in Yonatin, 2014:15) explains that reading comprehension is the readers' ability to comprehend the main idea, important detail, and the whole content of the text. It indicates that the comprehension of the student as a reader can be clarified when they are able to find the main idea of the text, to find the detail information (implicit and explicit information), and to re-explain the whole content of the text. Those are the key points that can be used as a consideration to conclude that the students are able to comprehend the content of the text given to them.

Thus, after comparing some definitions about reading comprehension, it is known that each expert has a different emphasis in defining reading comprehension. However, this study creates its own definition of reading comprehension. According to this study, the definition of reading comprehension is adjusted for the reading activity for senior high school students, especially for grade X. Definition of reading comprehension in this study in line with the statement in Core Competence and Basic Competence stated in 2013 Curriculum. As a result, students' ability in conducting a reading comprehension can be measured when they are able to: 1) identify the social function, text structure, and language feature of some English monologue texts; 2) differentiate a social function, text structure, and language feature of some English monologue texts; 3) predict the content of some English monologue texts; 4) compare English monologue texts; 5) retell English monologue texts; and 6) arrange English monologue texts.

According to the Department of National Education (in Daryanto and Dwicahyono, 2014:177-178), a module is a unit of teaching materials presented in the form of 'selfinstruction'. Further, the more detailed explanation is suggested by Rahardi (2006:16), a module is teachinglearning package or program consists of planning, implementation, to evaluation. It indicates that module is a complete guideline which is used by teachers in teaching. The guideline is arranged systematically from the beginning (planning) to the end (evaluation).

Then, Santoso (2011:61) adds that module is a learning media contains material, method, boundaries of learning materials, instructions and learning activities, exercises, and an evaluation which is designed systematically and attractive in order to achieve the expected competencies, also module can be used independently. This theory is supported by Richards and Schmidt (in Javed and Mohamed, 2016:20), module is an instructional unit or a series of linked activities and material in a course that is planned as a self-contained and independent learning sequence with its own objectives.

Component of module in this study needs to be concerned carefully. This study adapted the explanation about the module component through the following experts, they are Santoso (2011:62), Sudjana and Rivai (2007:134), Suryosubroto (in Wena, 2009:233), and Daryanto and Dwicahyono (2014:179-180). Thus, module component in this study are stated below:

a. Introduction. This is the initial part of the module. In this introduction, students will find:

1) Module description. It contains a general description of the module.

2) Module guideline. It contains explanation on how to use the module.

3) Module objective. It contains explanation about benefit that the students will get by using the module.

4) Self-assessment guideline. It contains some guidelines for self-assessment procedures that can be conducted by students.

b. Main content. This is the main part of module which contains about:

1) Explanation about English monologue texts (descriptive, recount, and narrative). The explanation itself consists of definition, social function, text structures and language features of texts.

2) Reading activities and practices. It consists of some reading examples and practices. Especially for this module, reading exercises accompanied by learning steps based on a scientific approach.

3) Summary about English monologue texts.

4) Vocabulary builder. It consists of difficult words contained in the module. Through a vocabulary builder, students can find the meaning of words, synonyms, antonyms, and or examples.

5) Key answers. It is used to facilitate students in checking their own achievement after conducting reading practices.

c. Evaluation. This is an evaluation section made specifically for summative tests. In this section students are facilitated with questions that can measure student knowledge after studying this entire module. In the evaluation section the students will find: 
1) Summative test related to descriptive, recount, and narrative text.

2) Key answers. It consists of answers that can be used by students to check their achievement independently after studying the three types of monologue texts contained in the module.

d. References. This references section is located at the end of the module. Students can find sources of information if they want to find more information about the contents of the module.

\section{METHOD}

\subsection{Research Design}

This study used descriptive research as the research design. Gay and Airasian (2000:275) stated that 'a descriptive study determines and describes the way things are'. Thus, by conducting this descriptive research, the researcher could describe deeply the fact about the students' needs on an availability of a reading comprehension module based on scientific approach for tenth grade students at SMAN 7 Padang.

2.2 Research Instrument
To gather data about teachers and students needs on an availability of reading comprehension module based scientific approach, instrument used in this study was a need analysis questionnaire. However, needs analysis questionnaire in this study was divided into two types: a. needs analysis questionnaire for students; and b. needs analysis questionnaire for teachers. The gotten through needs analysis questionnaires then would be used to design the reading comprehension module in this study. To get more details about questionnaires for students and teachers, please the following explanation.

a. Need Analysis Questionnaire for Students

The indicators for needs analysis questionnaire for students were adjusted to the needs of this study. As for the data needed from students were: 1) students' understanding of the learning monologue texts; 2) learning sources in school; 3) students' ways in understanding the English monologue texts; 4) students' needs on an availability of a reading module; 5) students' needs on a module content; 6) teachers' needs for module layout; and 7) Students' expectation for reading comprehension monologue text module based on scientific approach. Thus, indicators of this instrument could be seen in Table 1 .

Table 1 Indicators of Needs Analysis Questionnaires for Students

\begin{tabular}{|c|c|c|c|}
\hline No. & Aspects & Indicators & Items Number \\
\hline 1 & $\begin{array}{l}\text { Students' understanding of the } \\
\text { learning monologue texts }\end{array}$ & $\begin{array}{ll}- & \text { Students' understanding of learning the monologue texts } \\
\text { - } & \text { Students' perception in learning the monologue texts }\end{array}$ & $\begin{array}{l}1,2 \\
3\end{array}$ \\
\hline 2 & Learning sources in school & $\begin{array}{ll}- & \text { Availability of a specific reading source in school } \\
- & \text { Common reading source in school } \\
- & \text { Students' perception on the reading sources used in school }\end{array}$ & $\begin{array}{l}4 \\
5 \\
6\end{array}$ \\
\hline 3 & $\begin{array}{llr}\text { Students' } & \text { ways } & \text { in } \\
\text { understanding } & \text { the } & \text { English } \\
\text { monologue texts } & & \end{array}$ & $\begin{array}{l}\text { - Students' ways in understanding the English monologue texts } \\
\text { - Students' ways in conducting the reading comprehension activities } \\
\text { based on scientific approach }\end{array}$ & $\begin{array}{l}7 \\
8\end{array}$ \\
\hline 4 & $\begin{array}{l}\text { Students' needs on an } \\
\text { availability of a reading module }\end{array}$ & $\begin{array}{ll} & \text { Students' needs on an availability of a reading comprehension } \\
\text { monologue texts module } \\
\text { Importance of a reading comprehension monologue texts module }\end{array}$ & $\begin{array}{l}9 \\
10\end{array}$ \\
\hline 5 & $\begin{array}{l}\text { Students' needs on a module } \\
\text { content }\end{array}$ & $\begin{array}{ll}- & \text { Needs for the module introduction } \\
- & \text { Needs for the monologue texts topics } \\
- & \text { Needs for the types of reading practices } \\
- & \text { Needs for the numbers of reading practices } \\
- & \text { Needs for the key answers } \\
- & \text { Needs for the vocabulary builder } \\
- & \text { Needs for the summary } \\
- & \text { Needs for the references } \\
- & \text { Needs for the summative test } \\
\text { Needs for the language }\end{array}$ & $\begin{array}{l}11 \\
12 \\
13 \\
14 \\
15 \\
16 \\
17 \\
18 \\
19 \\
20\end{array}$ \\
\hline 6 & $\begin{array}{l}\text { Teachers' needs for module } \\
\text { layout }\end{array}$ & $\begin{array}{ll}- & \text { Needs for the color } \\
- & \text { Needs for the picture/illustration } \\
- & \text { Needs for the font } \\
- & \text { Needs for the module size }\end{array}$ & $\begin{array}{l}21 \\
22 \\
23,24,25 \\
26\end{array}$ \\
\hline 7 & $\begin{array}{lr}\text { Students' } & \text { expectation for } \\
\text { reading } \quad \text { comprehension } \\
\text { monologue text module based } \\
\text { on scientific approach }\end{array}$ & - Students' expectation to be achieved through the use of module & 27 \\
\hline
\end{tabular}

b. Need Analysis Questionnaire for Teachers

Data needed from the teachers in developing a reading comprehension module were about:

1) teachers' understanding of the scientific approach;

2) teachers' understanding of learning materials;

3) learning sources in school;
4) teachers' needs on an availability of a reading module;

5) teachers' needs on a module content;

6) teachers' needs for module layout; and

7) teachers' expectation for reading comprehension monologue text module based on scientific approach. 
As a result, the indicators of this instrument were stated in Table 2 below.

\section{Table 2 Indicators of Needs Analysis Questionnaires for Teachers}

\begin{tabular}{|c|c|c|c|}
\hline No. & Aspects & Indicators & $\begin{array}{l}\text { Items } \\
\text { Number }\end{array}$ \\
\hline 1 & $\begin{array}{l}\text { Teachers' understanding of } \\
\text { the scientific approach }\end{array}$ & $\begin{array}{ll}\text { - } & \text { Application of a scientific approach in teaching learning } \\
\text { activity } & \\
\text { - } & \text { Learning principles based on scientific approach } \\
- & \text { Reading comprehension activities based on scientific approach }\end{array}$ & $\begin{array}{l}1 \\
2 \\
3\end{array}$ \\
\hline 2 & $\begin{array}{l}\text { Teachers' understanding of } \\
\text { learning materials }\end{array}$ & - $\quad$ Nature of learning material & 4,5 \\
\hline 3 & Learning sources in school & $\begin{array}{ll}- & \text { Availability of a specific reading source in school } \\
- & \text { Common reading source in school }\end{array}$ & $\begin{array}{l}6 \\
7\end{array}$ \\
\hline 4 & $\begin{array}{l}\text { Teachers' needs on an } \\
\text { availability of a reading } \\
\text { module }\end{array}$ & $\begin{array}{l}\text { Teachers' needs on an availability of a reading comprehension } \\
\text { monologue texts module } \\
\text { Importance of a reading comprehension monologue texts } \\
\text { module }\end{array}$ & 8 \\
\hline 5 & $\begin{array}{l}\text { Teachers' needs on a } \\
\text { module content }\end{array}$ & $\begin{array}{ll}- & \text { Inclusion of an acknowledgement } \\
- & \text { Inclusion of a table of contents } \\
- & \text { Inclusion of core competence, basic competence, learning } \\
\text { indicators, and learning objectives } \\
- & \text { Presentation of an introductory chapter } \\
- & \text { Presentation of monologue texts chapter } \\
- & \text { Reading comprehension activities based on scientific approach } \\
- & \text { Monologue texts topics } \\
- & \text { Types of reading practices } \\
- & \text { Numbers of reading practices } \\
- & \text { Availability of key answers } \\
- & \text { Availability of vocabulary builder } \\
- & \text { Availability of summary } \\
- & \text { Availability of evaluation } \\
\end{array}$ & $\begin{array}{l}10 \\
11 \\
12,13 \\
14 \\
15 \\
16,17 \\
18 \\
19 \\
20 \\
21,22 \\
23 \\
24 \\
25,26 \\
27\end{array}$ \\
\hline 6 & $\begin{array}{l}\text { Teachers' needs for module } \\
\text { layout }\end{array}$ & $\begin{array}{ll}- & \text { Needs for a title } \\
- & \text { Needs for the color } \\
- & \text { Needs for the picture/illustration } \\
- & \text { Needs for the font } \\
- & \text { Needs for the module size }\end{array}$ & $\begin{array}{l}28 \\
29 \\
30 \\
31,32,33 \\
34\end{array}$ \\
\hline 7 & $\begin{array}{l}\text { Teachers' expectation for } \\
\text { reading comprehension } \\
\text { monologue text module } \\
\text { based on scientific approach }\end{array}$ & - $\quad$ Teachers' expectation to be achieved through the use of module & 35 \\
\hline
\end{tabular}

\subsection{Subject Data Source}

The subjects of data source in this study were students and English teachers at SMAN 7 Padang. The detailed explanation about this subject could be seen below:

\section{a. Students}

Students of SMAN 7 Padang who were become the source of data were the tenth grade students at that school. However, connected to the research interest, not all of the tenth grade students were the subject of the research. This study only took students at X IPA 2 as the research subjects. The numbers of students at this class were 36 persons. This research subject was taken by using purposive sampling technique (Gay and Airasian, 2000:183) with some following considerations.

1) The Curriculum Deputy of the school officially has recommended the classes of Mrs. Nurjanah as the research respondents.
2) Mrs. Nurjanah has a good willingness in helping the college students who wants to do a research in her class.

3) Mrs. Nurjanah has recommended class X IPA 2 as the respondents of the research since the students were categorized as representative of other classes.

4) The students at X IPA 2 were categorized have a good willingness to be the research subject.

b. Teacher

Teachers who were become the source of data were the English teachers who taught the tenth grade students at SMAN 7 Padang. Based on data, there were 4 people who taught at class X. However, not all teachers could be the subjects of research data source. Only three of them were made as research subjects. It was associated to the fact that one of them was being treated in hospital and was preparing for retirement. The subjects of this study were selected 
based on a purposive sampling technique (Gay and Airasian, 2000: 183).

\subsection{Technique of Data Collection}

Needs analysis questionnaires were used to gain some data and information that would be used as a basis for developing a reading comprehension module based on scientific approach for tenth grade students. In the process of collecting data through questionnaires.

\subsection{Technique of Data Analysis}

In analyzing quantitative data obtained through needs analysis questionnaire, the techniques implemented were:

a. Researcher gave some codes for the data which have been entered in the table. The explanation about the codes were stated below:

b. Each response given by students / teachers was calculated by using the following formula.

$$
P=\frac{f}{N} x 100
$$

P : Percentage

$f \quad$ : Frequency of responses

$\mathrm{N} \quad$ : Number of responses

Taken from Purwanto (2011)

c. After the number of responses was calculated, the frequency of each response was obtained.

d. Numerical data that have been obtained through MsExcel table was then transferred to Ms-Word. e. The numbers of frequency responses that have been moved into Ms-Word table were then analyzed by providing a description. It was conducted to gain description of the actual situation in the field and to make conclusion about the students and teachers' needs.

f. Data that have been obtained were then used as the basis for designing a reading comprehension module based on scientific approach.

\section{FINDING AND DISCUSSION}

The discussions related to the results of teachers and students' needs analysis were divided into three parts: a) Needs based on teachers' perspective; 2) Needs based on students' and teachers' perspectives; and 3) Conclusion of the teachers' and students' needs analysis.

a. Needs based on teachers' perspective

Data that would be discussed in this part were gotten through needs analysis questionnaires for teachers. As well stated, indicators of the questionnaires given to students and teachers were different. Especially for this part, this discussion was only about the points asked to teachers. It was because the teachers were considered able to provide appropriate responses compared to students. For more details, the discussion related to needs of module content and layout based on teachers' perspective could be seen in Table 3.

Table 3 Needs of module content based on teachers' perspective

\begin{tabular}{|l|l|l|}
\hline \multicolumn{1}{|c|}{ Aspects } & \multicolumn{1}{|c|}{ Teachers' Needs } & \multicolumn{1}{c|}{ Conclusion } \\
\hline Acknowledgement & No & $\begin{array}{l}\text { Acknowledgment would not be used as module } \\
\text { content. }\end{array}$ \\
\hline Table of content & Yes & $\begin{array}{l}\text { Table of content would be used as part of the } \\
\text { module content. The aim was to make it easier for } \\
\text { readers to find the page of the topic they want to } \\
\text { learn. }\end{array}$ \\
\hline Learning objectives & $\begin{array}{l}\text { Yes. } \\
\text { It is placed at the beginning of } \\
\text { each chapter. }\end{array}$ & $\begin{array}{l}\text { Learning objective would be included as part of } \\
\text { the module content. Each chapter in the module } \\
\text { would have learning objectives and be placed at } \\
\text { the beginning of each chapter. }\end{array}$ \\
\hline Monologue texts chapter & $\begin{array}{l}\text { Definition of text } \\
\text { Social function of text } \\
\text { Structure of text } \\
\text { Language feature of text }\end{array}$ & $\begin{array}{l}\text { The explanations that would be concluded as the } \\
\text { module contents were related to definition, social } \\
\text { function, text structure, and language feature of } \\
\text { the texts. }\end{array}$ \\
\hline $\begin{array}{l}\text { Reading comprehension activities } \\
\text { based on scientific approach }\end{array}$ & $\begin{array}{l}\text { Yes. } \\
\text { Learning stages based on scientific approach } \\
\text { would be included as module content. It aimed to } \\
\text { provide knowledge and familiarize students to } \\
\text { carry out learning activities based on scientific } \\
\text { approach in studying English monologue texts. }\end{array}$ \\
\hline Title & $\begin{array}{l}\text { Reading title that would be used for the product of this } \\
\text { Module based on Scientific } \\
\text { study was: Reading Comprehension Module } \\
\text { based on Scientific Approach. }\end{array}$ \\
\hline
\end{tabular}

b. Needs based on students' and teachers' perspectives

Data that would be discussed in this part were the findings of needs analysis questionnaires given to teachers and students. The data obtained through teachers' questionnaires were then compared with the data obtained through students' questionnaires. It was conducted to identify whether there was a common need for module content or not.

The following is a conclusion of all data that have been obtained through needs analysis questionnaires that have been filled out by teachers and students. This conclusion would be a guide in compiling the module content that would be developed in this study. It was very 
useful because the development of this module was a result of needs analysis conducted at SMAN 7 Padang. As a result, the contents of reading comprehension module that would be made in this study would consist of several aspects as stated in the following table (Table 4).

Table 4 Conclusion of the teachers' and students' needs for the module content

\begin{tabular}{|c|c|c|}
\hline Aspects & \multicolumn{2}{|c|}{ Module Contents } \\
\hline Table of content & Yes & \\
\hline Learning objectives & $\begin{array}{l}\text { Yes. } \\
\text { It would be placed at the beginning of } \mathrm{e}\end{array}$ & ch chapter \\
\hline Module introduction & $\begin{array}{ll}- & \text { Module description } \\
- & \text { Module guideline }\end{array}$ & $\begin{array}{ll}- & \text { Module objective } \\
- & \text { Self-assessment guidelines }\end{array}$ \\
\hline Monologue texts chapter & $\begin{array}{ll}- & \text { Definition of text } \\
- & \text { Social function of text } \\
- & \text { Structure of text } \\
- & \text { Language feature of text } \\
\end{array}$ & \\
\hline $\begin{array}{l}\text { Reading comprehension activities based on } \\
\text { scientific approach }\end{array}$ & $\begin{array}{l}\text { Yes. } \\
\text { It would use Indonesian and English. }\end{array}$ & \\
\hline Text topics & \begin{tabular}{cl}
\multicolumn{1}{l}{ Descriptive } \\
1. & Harrau valley \\
2. & Carocok beach \\
3. & Puncak lawang \\
4. & Pink beach \\
5. & Raja ampat \\
6. & Komodo island \\
7. & Everest \\
8. & The wave \\
9. & Manarola \\
Recount \\
1. & Padri War \\
2. & Belasting War \\
3. & Situjuah Incident \\
4. & Ambarawa War \\
5. & Bandung Sea of Fire \\
Narrative \\
1. & Malin kundang \\
2. & Twin Lake \\
3. & Singkarak Lake \\
4. & Crying Stone \\
5. & Roro Jongrang \\
\end{tabular} & $\begin{array}{ll}\text { 10. } & \text { Adityawarman museum } \\
\text { 11. } & \text { Lubang jepang } \\
\text { 12. } & \text { Benteng Van Der Capellen } \\
\text { 13. } & \text { Borobudur temple } \\
\text { 14. } & \text { Lawang sew } \\
\text { 15. } & \text { Monas } \\
\text { 16. Pyramids of Giza } \\
\text { 17. Sultan Ahmed blue mosque } \\
\text { 18. Coloseum } \\
\text { 6. The Release of East Timor } \\
\text { 7. Spanish Armada } \\
\text { 8. } \\
\text { 9. } & \text { Sing fall of Constantinople } \\
& \text { Malaysia } \\
\text { 6. } & \text { Sangkuriang } \\
\text { 7. } & \text { Three Sisters } \\
\text { 8. } & \text { Robin Hood } \\
\text { 9. Niagara Waterfall } \\
\end{array}$ \\
\hline Types of reading practices & $\begin{array}{ll}\text { - } & \text { Multiple choice } \\
\text { - } & \text { Pictured cued items } \\
\text { - } & \text { Multiple choice: for form- } \\
& \text { focused criteria } \\
\text { - } & \text { Matching tasks } \\
\text { - } & \text { Pictured-cued tasks } \\
\text { - } & \text { Gap-filling tasks }\end{array}$ & $\begin{array}{ll}- & \text { Short-answer tasks } \\
- & \text { Scanning } \\
- & \text { Ordering tasks } \\
- & \text { Skimming } \\
- & \text { Summarizing }\end{array}$ \\
\hline Number of reading questions & 10 questions & \\
\hline Key answers & $\begin{array}{l}\text { Yes. } \\
\text { It would be placed at the end of each ch }\end{array}$ & pter. \\
\hline Vocabulary builder & $\begin{array}{l}\text { Yes. } \\
\text { It would be placed at the end of each ch }\end{array}$ & pter. \\
\hline Summary & $\begin{array}{l}\text { Yes. } \\
\text { It would be placed at the end of each ch }\end{array}$ & pter. \\
\hline References & $\begin{array}{l}\text { Yes. } \\
\text { It would be placed at the end of the mo }\end{array}$ & \\
\hline Evaluation & $\begin{array}{ll}- & \text { Formative } \\
- & \text { Summative } \\
\end{array}$ & \\
\hline Language & Indonesian and English & \\
\hline Title & Reading Comprehension Module based & on Scientific Approach \\
\hline Color & Colorful & \\
\hline Picture/illustration & $\begin{array}{ll}\text { - } & \text { Animation/cartoon } \\
\text { - } & \text { Photograph } \\
\end{array}$ & \\
\hline Font & $\begin{array}{ll}- & \text { Comic sans ms } \\
- & \text { Adjustable size }\end{array}$ & \\
\hline Paper size & A4 & \\
\hline
\end{tabular}




\section{CONCLUSION}

Basically, the tenth grade students at SMAN 7 Padang have good enough enthusiasm to learn the English monologue text. It's just that, they do not fully get adequate facilities to support them in learning independently. Through the needs analysis activities carried out in this study, it can be concluded that several important points must be considered in making learning materials for students. With learning materials that are suitable to the needs of students, for example modules, the enthusiasm of students in learning English will increase because the material is made based on their needs and feels so close to them.

\section{REFERENCES}

[1] Abidin, Yunus. 2012. Pembelajaran Bahasa Berbasis Pendidikan Karakter. Bandung: PT Refika Aditama.

[2] Daryanto and Dwicahyono, Aris. 2014. Pengembangan Perangkat Pembelajaran. Yogyakarta: Gava Media.

[3] Departemen Pendidikan Nasional. 2004. Pedoman Umum Pengembangan Bahan Ajar. Departement Pendidikan Nasional, Direktoret Menengah Umum. Retrieved on August 2016. From: https://www.google.co.id/url?Panduan-Pengembangan-

Bahan-Pelajaran.doc\&usg

[4] Gay, L.R and Airasian, Peter. 2000. Educational Research: Competencies for Analysis and Application Sixth Edition. New Jersey: Prebtice-Hall, Inc.

[5] McNamara, Danielle S. 2007. Reading Comprehension Stategies. New York: Lawrence Erlbaum Associates, Inc.

[6] Purwanto. 2011. Evaluasi Hasil Belajar. Yogyakarta: Pustaka Pelajar.

[7] Rahardi, F. 2006. Panduan Lengkap Menulis Artikel, Feature, dan Esai. Depok: PT. AgroMedia Pustaka.

[8] Riduwan. 2012. Dasar-Dasar Statistika. Bandung: ALFABETA, cv.

[9] Richards, Jack C. 2001. Curriculum Development in Language Teaching. Cambridge: Cambridge Univerity Press.

[10] Santoso, Budi. 2011. Skema dan Mekanisme Pelatihan: Panduan Penyelenggaraan Pelatihan. Jakarta: TERANGI.

[11] Wena, Made. 2009. Strategi Pembelajaran Inovatif Jontemporer: Suatu Tinjauan Konseptual Operasional. Jakarta: Bumi Aksara. 